Acta vet. scand. $1970,11,247-253$.

From the Department of Food Hygiene, College of Veterinary Medicine, Helsinki, Finland.

\title{
THE INFESTIVENESS OF HEAT AND COLD EXPOSED DIPHYLLOBOTHRIUM LATUM PLEROCERCOIDS ON GOLDEN HAMSTER*)
}

\author{
By \\ K. Salminen
}

The most important food-hygienic countermeasure to prevent Diphyllobothrium latum infestation in man is to cut the lifecycle of the parasite by inactivation of the plerocercoids in fish to be eaten. This can be done e. g. by means of heat or cold treatments, in which the larvae are subjected to temperatures outside the range that they are able to survive. In order to determine the effect of high and low temperature treatments of fish by measuring the temperature changes in the fish, the lethal exposures of the larvae must be known. Immobilization of the larvae due to the treatments has generally been a criterion of their death and inability to cause infestation $(1,3,4,5,7)$. At the same time, however, most of these authors are aware of the possibility of misinterpretation caused by the reversible paralysis described in detail by Salminen \& Reinius (6). Therefore only a permanent immobilization has been considered to be a reliable indication of the death of the larvae. Since the cessation of movement, however, is only a characteristic feature of the response of the larvae to high and low temperature and does not unequivocally indicate death, a series of infestation experiments on golden hamsters (Mesocricetus auratus) (2) has been carried out to determine the correlation between larval motility and infestivity. A $56^{\circ} \mathrm{C} / 5 \mathrm{~min}$.

*) This study was supported by the National Research Council for Medical Sciences in Finland. 
heat exposure was found in previous studies to immobilize the larvae permanently, while a $50^{\circ} \mathrm{C} / 5 \mathrm{~min}$. exposure caused the typical reversible paralysis $(5,6)$. Concerning low temperature exposure, the plerocercoids were found to be permanently immobilized when they were subjected to an exposure analogous to the freezing of fish, and which is cut off when the temperature has decreased to $-10^{\circ} \mathrm{C}$. In corresponding conditions equally exposed larvae showed movement when the temperature was lowered to $-6^{\circ} \mathrm{C}(7)$.

\section{MATERIAL}

The plerocercoids utilized in the experiments were obtained from pikes brought to the laboratory from the Lappeenranta region (fish from Lake Saimaa, Southeastern Finland). The total number of plerocercoids was 450 .

Golden hamsters (Mesocricetus auratus) were used as test animals. Their age varied between $1-12$ months. The diet consisted of rutabaga, carrots, sunflower seed and a commercial mixture composed of the following ingredients: powdered milk without fat (3\%), ground feed made of fish (15\%), animal fat ( $1 \%)$, soybean grits ( $3 \%)$, ground feed made of oats $(20 \%)$, ground feed made of barley $(17.5 \%)$, ground feed made of wheat $(18 \%)$, maizena (10\%), wheat germ ( $2 \%)$, ground grass $(6 \%)$, feed yeast $(2.5 \%)$, a mixture of vitamins $A, D_{3}, B_{2}, C$ and $E$, choline, pantothenic acid, niacin and carophyll $(1 \%)$, calcium phosphate, sodium chloride, manganese sulfate, ferrous sulfate, coboltous sulfate, cuprous sulfate, zinc oxide, potassium iodide and amorphous sulfur (minute amounts). All the ingredients of the diet were available ad libitum to the animals. The total number of hamsters used in the tests was 90 .

\section{METHODS}

Isolation of the larvae

The plerocercoids in the fish were located by systematic slicing of the musculature and viscera by a scalpel. For the heat experiments the larvae were immediately transferred into horse serum. For the cold exposure the larvae were removed enclosed in small pieces of tissue, which were subjected to low temperature treatment. 
Heat and cold exposures of the larvae

The heat exposures were carried out in horse serum. Since the repeated pipettings seemed to injure the plerocercoids that had become fragile due to the exposure, the method was modified from that described before (5). For the tests the plerocercoids were sucked into Pasteur capillary pipettes which were then closed by melting the tip of the pipettes. The whole pipette with the plerocercoids was immersed in a pre-heated water bath and exposed for the appropriate time. Thus the handling of the larvae was easy and they were protected against mechanical damage.

The motility and integrity of the plerocercoids before the exposure were controlled by microscopical inspection.

The cold exposures were carried out in fish phantoms in the manner described before (7). After the freezing and thawing the larvae were removed and their integrity checked in horse serum.

\section{Infestation}

The heat or cold exposed plerocercoids were administered to the test animals under light inhalation anaesthesia. The larvae were transferred into the stomachs of the test animals by the aid of a urine catheter (Rüsch 8 ) fixed to a $5 \mathrm{ml}$ syringe, using serum as the conveying medium. The larvae were sucked into the tip of the catheter and ejected with light pressure. Simultaneously 5 plerocercoids were administered per animal. Faeces samples were investigated for the presence of parasite eggs both at the moment of infestation and 2-3 weeks thereafter.

The number of adult worms developed in the intestine of the test animals was studied $4-8$ weeks after the infestation. The animals were killed by decapitation under anaesthesia. The body cavity was opened by longitudinal incision and the intestine removed. The intestine was opened from the ventriculum to the caecum and the number of strobilas counted.

\section{RESULTS}

The results of the experiments are presented in Tables 1 and 2. In Table 1 the infestiveness of normal control larvae is shown. Out of the total of 150 plerocercoids administered 74 adult worms developed indicating $49 \%$ infestiveness. Adult worms developed in all infested hamsters except one; the number varied from 1 to 5 , the most common number being 2 . 
T a b l e 1. The infestiveness of unexposed plerocercoids in hamsters, which were given 5 larvae per hamster.

\begin{tabular}{ccccc}
\hline $\begin{array}{c}\text { Adult worms } \\
\text { developed } \\
\text { per hamster }\end{array}$ & Hamsters & & $\begin{array}{c}\text { Number of } \\
\text { plerocercoids } \\
\text { administered }\end{array}$ & $\begin{array}{c}\text { Number of } \\
\text { adult worms } \\
\text { developed }\end{array}$ \\
\cline { 2 - 4 } & number & $\%$ & & 5 \\
5 & 1 & 3.3 & 30 & 5 \\
4 & 6 & 20.0 & 35 & 21 \\
3 & 7 & 23.3 & 45 & 18 \\
2 & 9 & 30.0 & 30 & 6 \\
1 & 6 & 20.0 & 5 & 0 \\
0 & 1 & 3.3 & 150 & 74 \\
\hline Total & 30 & 99.9 & &
\end{tabular}

All the infested hamsters had eggs in the faeces $2-3$ weeks after the infestation. The general condition and appetite of the hamsters were unchanged, despite pronounced loss of weight. The loss of weight and the retardation of growth were correlated with the number of worms in the host. Intermittent diarrhoea and rugged appearance were common symptoms of the worm carriers. The worms were generally attached to the intestinal wall 3-6 cm aborally from the pylorus, and the strobila of worms extended down to the caecum. In a case of heavy infest-

T a b l e 2. The infestiveness of heat and cold exposed plerocercoids in hamsters, which were given 5 larvae per hamster.

\begin{tabular}{|c|c|c|c|c|c|}
\hline \multirow[t]{2}{*}{ Exposure } & \multirow{2}{*}{$\begin{array}{c}\text { Adult worms } \\
\text { developed } \\
\text { per hamster }\end{array}$} & \multicolumn{2}{|c|}{ Hamsters } & \multirow{2}{*}{$\begin{array}{l}\text { Number of } \\
\text { plerocercoids } \\
\text { administered }\end{array}$} & \multirow{2}{*}{$\begin{array}{c}\text { Number of } \\
\text { adult worms } \\
\text { developed }\end{array}$} \\
\hline & & number & $\%$ & & \\
\hline \multirow{2}{*}{$\begin{array}{l}56^{\circ} \mathrm{C} / \\
5 \mathrm{~min} .\end{array}$} & 0 & 21 & & 105 & 0 \\
\hline & & 21 & 100.0 & 105 & 0 \\
\hline \multirow{2}{*}{$\begin{array}{l}50^{\circ} \mathrm{C} / \\
5 \mathrm{~min} .\end{array}$} & 0 & 9 & & 45 & 0 \\
\hline & & 9 & 100.0 & 45 & 0 \\
\hline \multirow[t]{2}{*}{$-10^{\circ} \mathrm{C}$} & 0 & 20 & & 100 & 0 \\
\hline & & 20 & 100.0 & 100 & 0 \\
\hline \multirow[t]{4}{*}{$-6^{\circ} \mathrm{C}$} & 2 & 1 & 10.0 & 5 & 2 \\
\hline & 1 & 1 & 10.0 & 5 & 1 \\
\hline & 0 & 8 & 80.0 & 40 & 0 \\
\hline & & 10 & 100.0 & 50 & 3 \\
\hline
\end{tabular}


ation the lumen of the intestine was nearly completely obstructed by the tangled strobilas.

In Table 2 the results of the experiments with heat or cold exposed plerocercoids are presented. Of the heat exposed larvae none developed to an adult worm. The same result was obtained with the plerocercoids subjected to $-10^{\circ} \mathrm{C}$ exposure, while 3 larvae out of 50 exposed to $-6^{\circ} \mathrm{C}$ matured in the hamsters.

\section{DISCUSSION}

Diphyllobothrium latum, being a parasite of fish-eating species, does not have the golden hamster as a normal host. The results of control tests, however, show that the hamster is a fairly suitable host for the fish tapeworm, as indicated by the nearly $50 \%$ infestivity. Due to the administration method used the number of larvae given to each hamster was exactly known, making a quantitative evaluation of infestiveness possible. Preliminary tests showed that the simultaneous administration of 3 or 5 larvae per hamster did not influence infestiveness, and consequently 5 plerocercoids were given per hamster in order to be able to test a greater number of them.

The larvae were previously found to be permanently immobilized by a $56^{\circ} \mathrm{C} / 5 \mathrm{~min}$. heat exposure. The same result was obtained by cold exposure, which is similar to that seen in the freezing of fish and which is cut off when the temperature is lowered to $-10^{\circ} \mathrm{C}$. These exposures could thus be considered lethal, if larval motility is assumed to be an indication of viability. The results obtained confirm this assumption, and thus permanent immobilization seems to be a reliable indication of the death of the larvae. According to a previous work (6), the $50^{\circ} \mathrm{C} / 5 \mathrm{~min}$. exposure has not caused a permanent cessation of the movements; on the contrary, the larvae begin to move after a transient state of paralysis. The negative result of the infestation experiments with these larvae would justify us in considering the exposure lethal, but due to the small number tested the question may not be finally solved. However, the higher temperature/time $\left(56^{\circ} \mathrm{C} / 5 \mathrm{~min}\right.$.) used in the investigations of the heat preparation methods affords an additional margin of safety. The fact that $-6^{\circ} \mathrm{C}$ exposed larvae still developed to worms in the test animals emphasizes that only permanent immobilization is a reliable criterion of death. 
The total number of $56^{\circ} \mathrm{C} / 5 \mathrm{~min}$. and $-10^{\circ} \mathrm{C}$ exposed larvae was 105 and 100, respectively. As the infestiveness of normal control larvae was $49 \%, 51$ and 49 adult worms, respectively, should have developed if the infestiveness had been the same as that of the control larvae. The negative results indicate a probability of infestation smaller than $1 / 51$ and $1 / 49$, about $2 \%$, and a probability of about $98 \%$ that the larvae will not be able to cause infestation. These figures can be considered reliable, and it seems justified to use the exposures given as guide in advisory and instruction work directed against Diphyllobothrium latum infestation of man.

\section{REFERENCES}

1. Agranovsky, Z. M.: Experimental investigation of the action of different physical and chemical agents upon the survival of plerocercoids of Diphyllobothrium latum and the importance of these agents for the prophylaxis against diphyllobothriasis. Tr. Leningr. sanit.-gig. med. Inst. 1959, 47, 7-70. (In Russian).

2. Gnezdilov, V. G.: Khomiak (Mesocricetus auratus) kak potentsialnii ohouchatelnoi khoziain lentetsa shirokogo (Diphyllobothrium latum). (The hamster (Mesocricetus auratus) as potential definitive host of the dog tapeworm (Diphyllobothrium latum)). Dokl. Akad. Nauk SSSR, Otd. Biol. 1957, 114, 1328 -1330 .

3. Kajava, Y.: Några iakttagelser rörande den breda bandmaskens (Bothriocephalus latus) blåsmask. (Observations on the larvae of the broad tapeworm (Bothriocephalus latus)). Finska Läk.-Sällsk. Handl. 1913, 55, 700_707.

4. Pesonen, T. \& B.-J. Wikgren: Bandmasklarvernas salt- och temperaturtolerans. (The salt and temperature tolerance of the fish tapeworm larvae). Mem. Soc. Fauna Flora Fenn. 1958$1959,35,112-118$.

5. Salminen, K. \& H.-L. Kuosma \& L. Reinius: The effect of customary Finnish heat preparation methods on the infestiveness of Diphyllobothrium latum from fish to man. Acta vet. scand. 1966, 7, 101-124.

6. Salminen, $K . \& L$. Reinius: 'The reversibility of heat-induced paralysis in Diphyllobothrium latum plerocercoids. Nord. Vet.Med. 1967, 19, 546-549.

7. Salminen, $K$.: The effect of low temperatures on the motility of Diphyllobothrium latum plerocercoids. Acta vet. scand. 1970, $11,236-246$. 

plerocercoids

\section{SUMMARY}

The infestiveness of heat $\left(56^{\circ} \mathrm{C} / 5 \mathrm{~min}\right.$. and $50^{\circ} \mathrm{C} / 5 \mathrm{~min}$.), and cold $\left(-10^{\circ} \mathrm{C}\right.$ and $\left.-6^{\circ} \mathrm{C}\right)$ exposed Diphyllobothrium latum plerocercoids was studied by administration to golden hamsters (Mesocricetus auratus). The cold exposed larvae were subjected to an exposure, analogous the freezing of fish and which is cut off when the temperature has declined either to $-6^{\circ} \mathrm{C}$ or $-10^{\circ} \mathrm{C}$. The plerocercoids were administered to the hamsters under inhalation anaesthesia, 5 larvae per hamster. Out of 150 normal control plerocercoids administered on 30 hamsters, 74 adult worms developed, indicating $49 \%$ infestiveness. Tests carried out with $10556^{\circ} \mathrm{C} / 5 \mathrm{~min}$. exposed larvae on 21 hamsters, $4550^{\circ} \mathrm{C} / 5 \mathrm{~min}$. exposed larvae on 9 hamsters, and 100 larvae exposed to $-10^{\circ} \mathrm{C}$ on 20 hamsters all gave negative results, while out of $50-6^{\circ} \mathrm{C}$ exposed larvae on 10 hamsters 3 developed to adult worms. The results show that the $56^{\circ} \mathrm{C} / 5 \mathrm{~min}$. and $-10^{\circ} \mathrm{C}$ exposed larvae, which in previous studies have been considered to be inactivated on the basis of the resultant permanent immobilization, were not able to develop further in the host. Thus permanent immobility seems to be a reliable criterion of larval death.

\section{SAMMANFATTNING}

Värme- resp. kylbehandlade Diphyllobothrium latum plerocercoiders förmåga att invadera guldhamster.

Infestiviteten av Diphyllobothrium latum plerocercoider utsatta för värme- $\left(56^{\circ} \mathrm{C} / 5 \mathrm{~min}\right.$. och $50^{\circ} \mathrm{C} / 5 \mathrm{~min}$. $)$ och kylbehandlingar $\left(-10^{\circ} \mathrm{C}\right.$ och $\left.-6^{\circ} \mathrm{C}\right)$ undersöktes med användning av gyllene hamstrar (Mesocricetus auratus) som försöksdjur. De kylexponerade larverna utsattes för en likadan behandling som den, vilken äger rum vid nedfrysning av fisk och vilken avbryts då temperaturen sjunkit till $-6^{\circ} \mathrm{C}$ eller $-10^{\circ} \mathrm{C}$. Plerocercoiderna fördes in på hamstrarna under ytlig inhalation narkos, 5 larver per hamster. Av 150 normala kontroll plerocercoider införda på 30 hamstrar utvecklades 74 vuxna maskar, vilket tyder på en infestivitet på 49 \%. Försök utförda med 105 larver utsatta för $56^{\circ} \mathrm{C} / 5 \mathrm{~min}$. på 21 hamstrar, 45 larver utsatta för $50^{\circ} \mathrm{C} / 5$ min. på 9 hamstrar samt 100 larver utsatta för $-10^{\circ} \mathrm{C}$ på 20 hamstrar gav alla negativa resultat, medan av 50 larver utsatta för $-6^{\circ} \mathrm{C}$ på 10 hamstrar utvecklades 3 stycken till fullvuxna maskar. Resultaten visar, att larverna, utsatta för $56^{\circ} \mathrm{C} / 5 \mathrm{~min}$. och $-10^{\circ} \mathrm{C}$ behandlingar, och vilka i tidigare undersökningar har ansetts bli inaktiverade på grund av den resulterande permanenta immobilisationen, utvecklades ej vidare i värden. Sålunda är permanent immobilitet tydligen ett pålitligt kriterium för larvens död. 